\title{
AS\&I:
}

\section{O chamado do Curupira}

\author{
Virgínia Codá ${ }^{1}$, Elidiomar Ribeiro da Silva ${ }^{1}$, Marcelo Simão de Vasconcellos ${ }^{1}$
}

\section{AUTHOR AFILIATIONS}

1 - Universidade Federal do Estado do Rio de Janeiro

\section{CONTACT}

virginiacoda@gmail.com

\begin{abstract}
The present work aimed to analyze the potential of a serious game of the Role Playing Game genre as an instrument of Scientific Communication. For this analysis, a case study was made, based on an RPG entitled "Curupira's call", which was tested in game sessions with groups of adults aged between 18 and 74 years. Two groups were composed of people who had never played table RPGs, and another group with people experienced in this type of game. After each session, focus groups were chosen, for a more in-depth understanding of the players' point of view, and comment on decisions that the acquired groups had made during the game. The game sessions and the interview ones were recorded, transcribed and analyzed. Among the results found and commented on, subjects such as immersion, first contact with some scientific conceptions, experience of the game, use of previous knowledge, contextualization and an adequate understanding of concepts, such as Scientific Dissemination, are observed.
\end{abstract}

Keywords: RPG, Science Communication, games, Serious Games.

\section{RESUMO}

O presente trabalho teve como objetivo analisar o potencial de um jogo sério do gênero Role Playing Game como instrumento de Divulgação Científica. Para essa análise, foi feito um estudo de caso, tendo como base um RPG intitulado "O chamado do Curupira", o qual foi testado em sessões de jogos com grupos de adultos com idades que variavam entre 18 e 74 anos. Dois grupos foram compostos por pessoas que nunca tinham jogado RPG de mesa, e outro com pessoas experientes nesse tipo de jogo. Depois de cada sessão, foram feitas entrevistas de grupos focais, com a finalidade de compreender o ponto de vista dos jogadores, de forma mais aprofundada, e comentar sobre decisões que os grupos haviam tomado durante o jogo. As sessões e as entrevistas foram gravadas, transcritas e analisadas. Dentre os resultados encontrados e comentados, observam-se assuntos como imersão, primeiro contato com alguns assuntos científicos, relato de experiência do jogo, utilização de conhecimentos prévios, 
contextualização e um adequado entendimento de conceitos, como Divulgação Científica.

Palavras-chave: RPG, Divulgação Científica, jogos, Serious Games.

\section{INTRODUÇÃO}

Uma das responsabilidades de ser cientista é compartilhar a Ciência com todos. Solidificar a ponte Ciência-sociedade é uma iniciativa importante e necessária, principalmente para ampliar a autonomia de cada cidadão frente aos avanços do conhecimento. Dessa forma, torna-se cada vez mais necessária uma transposição da linguagem técnica e formal para outra mais acessível à sociedade e seus diferentes contextos. Essa mediação pode ser feita através da Divulgação Científica (BURNS et al., 2003).

$$
\text { Divulgação Científica (DC), ou }
$$
popularização da Ciência, é o termo empregado para a utilização de recursos, técnicas, processos e produtos para a veiculação de informações científicas, tecnológicas ou associadas a inovações, focadas no público leigo (BUENO, 2010). Enquanto a Divulgação Científica almeja comunicar o conhecimento científico para um público não especializado, utilizando uma linguagem acessível e considerando a informação já adquirida pelo receptor, a Difusão e a Disseminação têm significados diferentes, mas que muitas vezes são confundidos. O primeiro visa compartilhar o conhecimento independente de quem seja o receptor, e o segundo tem como foco propagar o conhecimento para os pares, aqueles que também são especializados no assunto. Ou seja, a Divulgação e a Disseminação são formas específicas de Difusão. 
De acordo com Albagli (1996), a divulgação da Ciência está orientada em três sentidos: I. Sentido cívico, o qual se transmite a informação científica para ampliar a consciência do cidadão a respeito de questões sociais, econômicas e ambientais; II. Sentido de mobilização popular, que é transmitir informação científica para instrumentalizar atores a intervir melhor no processo decisório, como políticas públicas; III. Sentido educacional, com o intuito de transmitir e esclarecer informação científica já aprendida previamente no educação-formal. Em relação ao sentido educacional, Neves e Massarani (2016) observam que nos últimos anos, no Brasil, há um maior engajamento da comunidade científica, instituições de pesquisa e universidades, em atividades que popularizam a Ciência. Essas atividades, frequentemente, têm como foco o público infantil, estimulando o contato com a Ciência desde cedo e a tornando parte da rotina das crianças, mas nada impede que também tenham como foco o público adulto.

Uma área que exemplifica bem a complementaridade entre educação e Divulgação Científica é a Biologia Cultural. De acordo com
Da-Silva e Coelho (2015), a biologia cultural está relacionada às Ciências biológicas e da natureza, e cumpre o papel de levar a crianças, jovens e adultos assuntos de botânica, microbiologia, zoologia, ecologia, entre outros, de forma facilitada, interativa e contextualizada ao dia a dia. Os temas vão desde os mais específicos, como caracterização morfológica, até conceitos biológicos gerais, como a educação ambiental. E podem ser extraídos a partir de livros, filmes, desenhos e, é claro, jogos.

Um influente elemento do cotidiano que passou a ser bastante utilizado no contexto da educação é o jogo. Embora existam diversas definições de jogo, no presente trabalho será adotada a definição de Johan Huizinga, historiador holandês com contribuições em diversos temas, como a história moderna cultural e o jogo como elemento da cultura:

\footnotetext{
Uma atividade ou ocupação voluntária, exercida dentro de certos e determinados limites de tempo e espaço, segundo regras livremente consentidas, mas absolutamente
} 
obrigatórias, dotada de um fim

em si mesmo, acompanhado de um sentimento de tensão e alegria e de uma consciência de ser diferente da vida cotidiana. (HUIZINGA, 2020)

Nessa definição, percebe-se uma preocupação do autor quanto à importância de associar jogos ao prazer, espontaneidade e alegria, fatores que são interessantes para a Divulgação Científica, por poderem facilitar a contextualização e o rompimento da formalidade que muitas vezes é associada à Ciência e a algum conteúdo científico que possa ser apresentado ao público não-especializado.

Pesquisadores como McFeetors e Palfy (2018), sustentam que quando se utiliza um jogo como prática educativa, habilidades são desenvolvidas de forma prazerosa. Kishimoto (2017) identifica esse entusiasmo no momento em que os jogadores participam por vontade própria e de forma descontraída e, muitas vezes, não percebem que há um aprendizado por trás de todo aquele entretenimento. Além disso, há o fator de socialização, observado por Hsiao
(2007), que permite que os jogadores possam compartilhar informações e experiências, ajudando um ao outro num contexto de aprendizagem distribuída.

Nesse sentido, surgem os jogos sérios (Serious Games), que são uma opção ao conceito de jogos educativos, e denominam aqueles jogos que visem causar efeitos no mundo real. Jogos sérios são usados para instruir e educar, mas também para comunicar e conscientizar o público sobre causas artísticas, religiosas, políticas e sociais (VASCONCELLOS, 2013). Enquanto os jogos educativos têm uma grande finalidade de fixar e ensinar assuntos das disciplinas estudadas nas escolas, Becker (2018) relatou que os jogos sérios têm o objetivo de mudar comportamentos, saúde, entendimento e conhecimento, sendo criados com uma grande preocupação de ir além da possibilidade de o jogador ter aprendido alguma coisa que possa ser utilizada apenas em sala de aula. Os jogos sérios podem ser apresentados nos mais variados gêneros de jogos, tanto digitalmente quanto analogicamente, um exemplo é através dos Role Playing Games. 
Role Playing Game (RPG) é um gênero de jogo que se originou a partir de jogos de estratégia militar de tabuleiro. No século XVIII, militares surgiram com um método de treinamento de estratégia que buscava reproduzir batalhas históricas em um tabuleiro de jogo, dando aos estudantes uma visão mais ampla dos confrontos e permitindo-lhes tomar diferentes ações e ver seus resultados imediatamente. Mais tarde, esta prática se popularizou para além das academias militares e se tornou um passatempo para o resto da sociedade, o qual buscava reproduzir tais batalhas como meio de entretenimento.

Aos poucos, elementos fantasiosos foram sendo introduzidos, inspirados em sagas, como as escritas por J. R. R. Tolkien. Além disso, incluiuse um tipo de jogador diferente dos demais, que atuava tanto como juiz quanto como o narrador da história: o mestre do jogo. Finalmente, em 1974 foi lançado o jogo Dungeons \& Dragons, iniciando oficialmente o gênero de jogos que ficou conhecido como RPG (VASCONCELLOS, 2013).

A narração de um RPG se desenvolve entrelaçada com desafios que o grupo de jogadores precisa superar colaborativamente. Estes desafios podem ser na forma de batalhas, investigação de crimes, resolução de enigmas ou debates entre os personagens, por exemplo. E, normalmente, são influenciados por valores resultantes de lançamentos de dados. O mestre narra os desfechos de cada desafio, sejam eles benéficos ou prejudiciais aos personagens dos jogadores, podendo até mesmo incluir possíveis mortes, e a narrativa do jogo segue adiante.

Souza (2015) fez uma análise bibliográfica a fim de investigar a possível efetividade de RPGs como instrumento de fixação de assuntos relacionados à educação ambiental. Ela concluiu que, justamente por alguns alunos considerarem explicações referentes à biologia pouco atraentes e assuntos que apenas precisam ser memorizados e não realmente entendidos, os RPGs deveriam ser utilizados na educação, por permitirem que o jogador seja um agente ativo na construção de seu conhecimento. Depreende-se daí que o uso dos RPGs na educação ambiental seria particularmente relevante, uma vez que esta é 
uma temática interdisciplinar e tão importante na atual conjuntura mundial.

Nesse sentido, o presente trabalho foi desenvolvido a partir de um estudo de caso com a finalidade de analisar os RPGs como instrumentos de contextualização e popularização de conceitos científicos.

\section{METODOLOGIA}

\section{0 jogo}

Para esta pesquisa, optou-se por um Role Playing Game (RPG) por ser um gênero já bastante utilizado na educação e ter uma mecânica de jogo suscetível a incentivar a criatividade, a cooperação, a contextualização, interdisciplinaridade e outros fatores que são extremamente relevantes não apenas para uma experiência interessante e divertida, como também num enquadramento relacionado à Divulgação Científica.

Para um jogo mais completo, foi analisado o material criado pelos autores Carlos Klimick e Eliane Bettocchi, denominado Incorporais e hospedado na página http://www.historias.interativas.nom.br/. $\quad \mathrm{O}$ material criado por eles permite um maior entendimento dos tópicos fundamentais que precisam estar presentes na estrutura de criação de um RPG que tenha foco na educação, seja ela formal, não formal ou informal.

Com base no material analisado, foi adaptada uma ambientação de Role Playing Game que deu origem ao jogo "O chamado do Curupira" (figura 1). Esse RPG tinha como cenário o Brasil contemporâneo subdividido nos principais biomas: Amazônia, Caatinga, Cerrado, Mata Atlântica, Pampa e Pantanal.

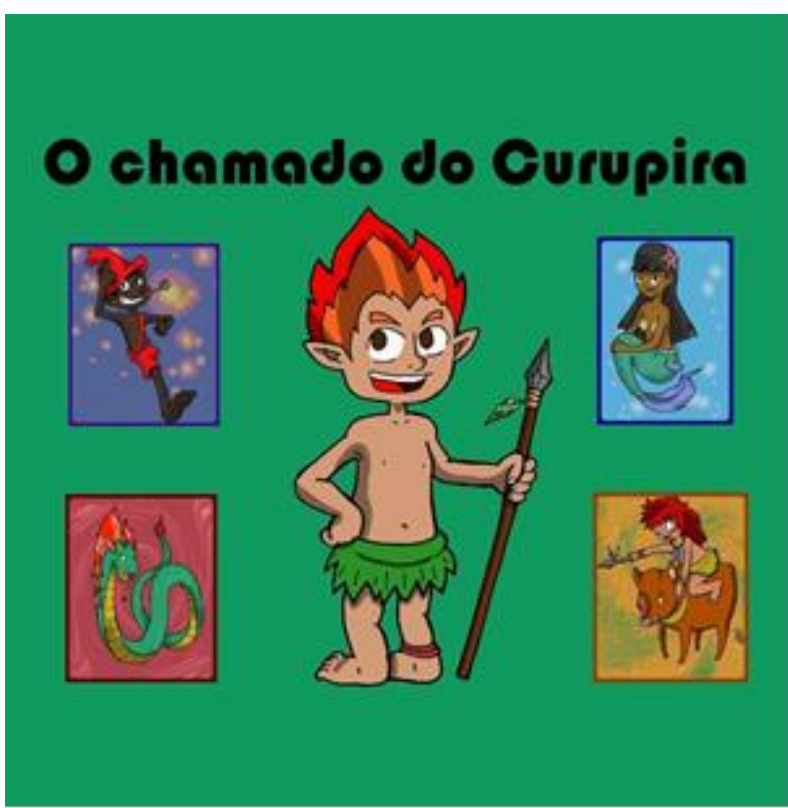

Figura 1: Capa do RPG "O chamado do Curupira", com os personagens do jogo. llustração: Toni Cirilo, 2019. 
A narrativa principal e os desafios do jogo serão apresentados a seguir:

- O Curupira passou muito tempo sumido, e os outros personagens do folclore ficaram preocupados, já que ele nunca tinha sumido por tanto tempo antes. Resolveram, então, fazer uma reunião para saber se alguém sabia do paradeiro do Curupira, ou se ele tinha sido visto em algum lugar nos últimos tempos. No meio da reunião, o Curupira aparece e diz que ficou todo esse tempo sumido, porque estava andando pelo Brasil e conhecendo cada canto do nosso país. Ele menciona sua preocupação com o que estava acontecendo com o Brasil, e fala de alguns problemas ambientais que estão acontecendo no país, ocasionado pelos vilões. A turma aceita ajudar e, então, é realizada uma votação para mandar as quatro criaturas que irão acompanhar o Curupira em suas missões. Assim, são escolhidos o Boitatá, o Caipora, a Iara e o Saci.

- Amazônia: O Curupira conta que viu um rastro de desmatamento no coração da mata. Muitos animais já morreram por outras árvores terem sido derrubadas, e esse desequilíbrio faz com que a comida fique mais escassa. As árvores são importantes para abrigar os animais da chuva, que ocorre quase todos os dias. Ele traz a notícia de que a próxima árvore a ser cortada por eles é uma árvore bem alta, antiga, com tronco bem grosso, cuja copa é capaz de abrigar dezenas de espécies de aves, insetos, mamíferos, entre outros. A árvore parece uma verdadeira cidade, que abriga várias espécies. Curupira avisa que os animais estão desesperados, pois cada vez mais seus ninhos e suas casas estão sendo destruídas pelos vilões. Eles têm motosserras enormes, gasolina e isqueiros, além disso, três deles estão armados. No dia seguinte, lá estão os vilões prontos para cortarem não só aquela árvore, como várias outras. Eles ainda não viram nossos heróis.

- Caatinga: os heróis chegam à Caatinga e ficam assustados. Está tudo completamente seco, muito mais do que o normal. O chão está rachado, o pouco de vegetação morreu e podem avistar ossos de mamíferos que não resistiram à seca e à fome. O céu não tem uma nuvem. Ao longe, avistam um homem sentado em um banco de madeira, chorando, em frente à sua casa. Se aproximam 
dele e percebem que ele está mais magro do que deveria. O homem diz que não chove há muito tempo e mesmo quando chovia, no solo já não nascia nada, estava completamente sem vida por tanto que os vilões tinham mexido para tirar água apenas para eles e suas fazendas. O homem comenta que, em alguns quilômetros de distância, existe uma fazenda dessas, mas o povo que ainda está vivo não pode entrar para beber água e comer, muito menos os animais.

- Cerrado: o grupo chega ao cerrado e toma um susto. A água está amarela e o solo com grandes crateras. Poucas plantas e poucos animais são vistos naquela área. Pode-se perceber homens, mulheres e crianças trabalhando na sujeira, em meio ao cheiro químico forte, a mando dos vilões, cavando e cavando em busca de minérios. Várias pessoas estão no seu limite e já não aguentam mais. O rio, próximo a eles, está completamente poluído, e são raríssimos os peixes que conseguem viver nele, já muito doentes. Uma criança de 10 anos fala para eles que foi vendido pelos pais para trabalhar naquele local e que sonha em sair e poder estudar para ser um professor. As pessoas não podem fugir, porque os vilões detêm todos os documentos e ficam prometendo pagar muito dinheiro a elas em breve. Sem esse dinheiro, elas não têm como sobreviver fora dali. Sabe-se que o principal vilão é muito rico e aparece por lá uma vez na semana, de jatinho, para conferir o andamento das obras, ele está sempre cercado por três outros vilões armados.

- Mata Atlântica: os animais estão assustados com tanto barulho, e nunca viram tantas luzes antes. Chegaram a pensar que a luz do dia tinha durado 24h, já que estava sempre claro, e, com isso, os animais que saíam apenas de noite, tiveram que se manter escondidos. O grupo descobre que os vilões estão construindo cada vez mais casas e prédios perto da mata, desmatando para poder construir. Uma das construções está sendo feita numa parte da mata já bastante danificada, com o solo enfraquecido, arenoso e bastante íngreme. Mas os vilões não ligam, pois vão conseguir muito dinheiro com a venda daqueles imóveis. Os insetos terminaram morrendo, porque os vilões acham que eles perturbam muito e mandaram 
dedetizar todo o local em volta. Amanhã, o chefe dos vilões irá fazer uma grande festa para inaugurar o novo prédio (que já está começando a rachar, mas os moradores não sabem), e irá anunciar a área que será desmatada para construírem a quadra de futebol.

- Pampa: os animais mais velhos reclamam que antigamente era tudo diferente. Todos viviam em harmonia e não faltava nada. Depois que os vilões levaram animais e plantas novos para aquela área, a competição por comida ficou maior e o solo ficou sobrecarregado. Eles não culpavam os novos animais e plantas que tinham chegado, os coitados estavam dando duro para se adaptar e diziam que a saudade de casa apertava, já que foram roubados pelos vilões de outros cantos do Brasil. Com o passar do tempo, acreditava-se que ia ficar muito difícil para todos os seres vivos dali e a busca pela sobrevivência terminaria resultando em morte de vários deles. Os personagens estão vendo uma fumaça ao longe e está escurecendo, com os animais noturnos começando a se manifestar
- Pantanal: o grupo chega ao Pantanal e fica assustado por não ver nenhum animal. Quando vai anoitecendo, boitatá percebe que os animais vão surgindo. O grupo pergunta o que está acontecendo, e eles falam que estão com medo de sair e serem caçados. Até os peixes preferem ficar entre as pedras ou escondidos o mais fundo possível. Os vilões são os responsáveis pela caça e pesca ilegal e estão vendendo lindas aves para outros países. Os animais contam que têm vários animais presos em um galpão, em gaiolas, e que os vilões vão levar embora amanhã em aviões para outros lugares. Uma arara azul está desesperada para encontrar seus filhotes.

Apesar do jogo possuir esses desafios propostos, o Mestre do Jogo tinha liberdade para improvisar o quanto achasse necessário, sendo esse um dos fatores fundamentais para a sensação de que, por mais que jogassem no mesmo bioma, nunca seria da mesma forma, com a adaptação do desenrolar da história de acordo com as ações dos jogadores.

Foram estipuladas algumas regras básicas e, para elas, os três dados de seis lados eram 
necessários. De uma forma geral, para que as ações tivessem efeito, os jogadores precisavam tirar no mínimo 12 na soma dos três dados. Em casos de ações conjuntas, seria um total de 24 para dois jogadores, 36 para três e 48 se fosse uma ação do grupo inteiro. Ainda assim, dependendo das ações dos jogadores e de como estavam seus personagens (machucados, abalados, confiantes, entre outros), esses valores poderiam ser alterados para mais ou menos, de acordo com o julgamento do mestre.

Os jogadores poderiam pedir a ajuda do personagem Curupira uma vez em cada bioma. Sendo assim, se resolvessem fazer uma ação em grupo, cuja soma mínima tivesse que ser 48 e terminassem somando 45 , poderiam recorrer ao Curupira para que ele fizesse uma ação para ajudá-los a completar a pontuação. Em contraponto a isso, se pedissem a ajuda do Curupira, teriam, obrigatoriamente, desvantagens iniciais quando passassem para o bioma seguinte, como algum machucado que os acompanharia por algumas rodadas.

Como mencionado na plataforma Incorporais, as regras são importantes para organizar as ações dos personagens, determinado o que conseguem ou não fazer, assim como considera o acaso. Os jogadores eram livres para escolher os personagens que quisessem, com exceção do Curupira, que, obrigatoriamente, era interpretado pelo Mestre do Jogo. O Mestre do Jogo foi o único jogador com personagem prédefinido, e esteve em todas as sessões de jogo, com os diferentes grupos. Para este papel, foi escolhido um jogador de RPG com anos de experiência, biólogo e divulgador científico. Reuniões foram feitas via videoconferência para inteirá-lo da história, dos desafios e dos personagens. Foi decidido ter a mesma pessoa como mestre em todas as sessões para que um padrão narrativo fosse seguido, e para que suas observações também fossem consideradas, tanto no momento da entrevista, quanto após.

$$
\text { Cada personagem (figura 2) tinha }
$$
habilidades únicas, e os quatro que eram utilizados pelos participantes da pesquisa correspondiam aos elementos água, fogo, terra e ar. O Caipora controlava a terra, além de falar com os animais, ter uma ótima pontaria, invocar animais e soltar uma fumaça pela boca, que fazia 
a pessoa dormir por até $4 \mathrm{~h}$. O Boitatá controlava o fogo, tinha uma excelente visão noturna e manipulava seres vivos através do olhar. A Iara manipulava a água, tinha uma voz mágica (capaz de persuadir o humano que quisesse), tinha pernas fora d'água e cauda de sereia dentro d'água, além de ser boa em combate. O Saci controlava o ar, tinha poderes apenas com a carapuça, era furtivo, especialista em ervas e fazia, não só ele mesmo, como coisas desaparecerem e aparecerem onde ele queria. Além desses, havia o Curupira, sempre conduzido pelo Mestre do Jogo, que era chamado apenas em momentos de urgência ou para falar os desafios, seus poderes eram: muito forte, ágil, furtivo, grande poder de convencimento, além de falar com animais, como seu primo Caipora.

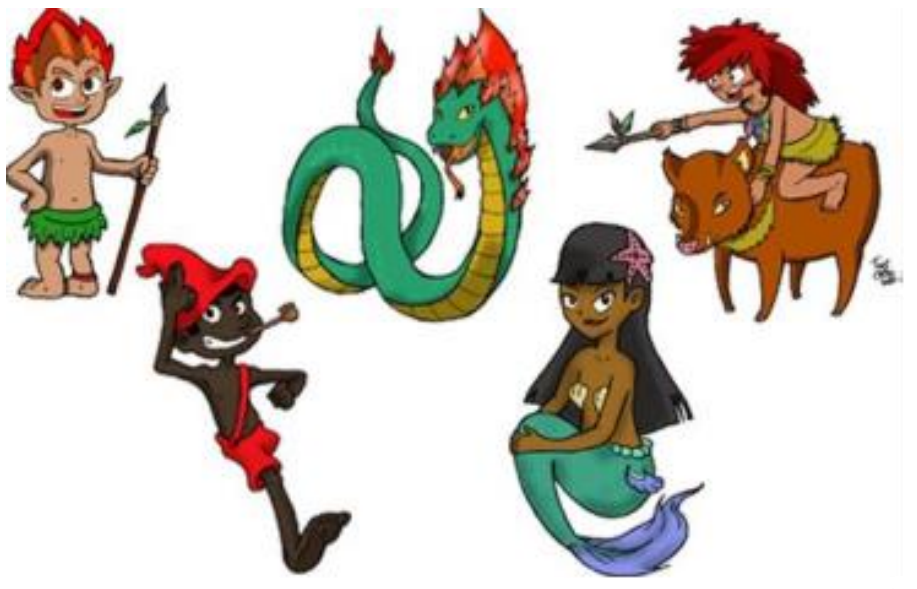

Figura 2: Personagens do jogo "O Chamado do Curupira". Na fileira superior, da esquerda para a direita: Curupira, Boitatá e Caipora. Na fileira inferior: da esquerda para a direita: Sacie lara. llustração: Toni Cirilo, 2019.

Após o Mestre do Jogo ler a introdução e cada jogador escolher o personagem que iria interpretar, o grupo escolhia um dos biomas para iniciar sua aventura. Cada bioma tinha um desafio em aberto (o objetivo não era explicitado), desta forma, cabia a cada grupo definir as ações que iriam tomar para resolver o que quer que achassem que era o problema. A escolha do objetivo em aberto tornou-se relevante para avaliar o grau de percepção dos jogadores em relação às questões que eram apresentadas para eles.

\section{Coleta e análise de dados}

O estudo de caso foi feito a partir de três grupos de quatro pessoas, em cada. Dois grupos 
de pessoas maiores de idade sem experiência em jogar RPG e um grupo com pessoas maiores de idade com experiência em jogar RPG. As idades variaram entre 18 e 73 anos. Os participantes foram comunicados que a pesquisa já tinha passado pelo Comitê de Ética da Escola Politécnica Joaquim Venâncio, da Fiocruz - Rio de Janeiro, e receberam vias do Termo de Consentimento Livre e Esclarecido. Todos concordaram em participar da pesquisa.

Sobre os estudos de caso, essa metodologia de análise está caracterizada segundo Yin (2014):

É uma análise empírica que
investiga um fenômeno
contemporâneo dentro de seu
contexto da vida real. Em
outras palavras, você utiliza o
método de estudo de caso
porque, deliberadamente, quer
cobrir as condições
contextuais, acreditando que
podem ser altamente
pertinentes ao seu fenômeno
de estudo (YIN, 2014).

Segundo Godoy (1995), o pesquisador que opta pelo estudo de caso deverá estar aberto às suas descobertas e, por mais que tenha iniciado seu trabalho a partir de um esquema teórico, deverá se manter atento a novos elementos que possam surgir ao decorrer da pesquisa. Ainda que o estudo de caso tenha um teor qualitativo, nada impede de serem analisados alguns dados quantitativos, e o relatório final apresenta um estilo informal e narrativo, ilustrando citações, exemplos e descrições.

As sessões de jogo duraram cerca de $2 \mathrm{~h}$ e passaram pelo processo de observação participante, que é descrita por Sandiford (2015) como um meio de tentar compreender e contextualizar os dados observados. $\mathrm{O}$ fato de $\mathrm{o}$ observador estar presente no mesmo local e tempo que os observados permite que, durante as entrevistas, aprofundem explicações de momentos que foram experimentados por ambos, além de ser possível fazer anotações imediatas de algo que chamou a atenção do observador. Foi utilizado, também, um caderno de campo com a finalidade de relatar e destacar momentos considerados relevantes.

O método de entrevista em grupos focais foi utilizado no caso dessa pesquisa, pelos 
participantes terem compartilhado a experiência de jogo juntos. Dessa forma, podem ser observadas tanto as interpretações e opiniões individuais, como do grupo. De acordo com Iervolino e Pelicione (2001), a essência do grupo focal consiste na interação entre os participantes e o pesquisador, que objetiva colher dados a partir da discussão focada em tópicos específicos e diretivos.

Algumas questões serviram de roteiro para estimular debates sobre determinadas questões importantes para a pesquisa, ao decorrer da entrevista em grupo focal. Essas perguntas serão apresentadas a seguir:

I- O que vocês acharam da experiência?

II- Quais foram as dificuldades durante o jogo?

III- Qual parte da sessão de hoje vocês mais gostaram?

IV- O que vocês acham de jogos, como esse, que se desenvolvem a partir de uma narrativa?

V- Quais desafios vocês resolveram baseados em conhecimentos prévios?
VI- Se você tivesse as habilidades do seu personagem, o que você faria?

VII- Como você lida com esses problemas ambientais na vida real?

VIII- O que é divulgação científica, para você?

XIX-O que você acha de jogos como instrumento na divulgação científica?

X- Para você, o RPG pode ou não ser um instrumento eficaz de divulgação científica? Por que?

XI- Que assunto de Ciências você acha que daria um bom RPG?

XII- Teve algum assunto que você teve contato pela primeira vez durante essa sessão? Qual?

XII- Você gostaria de fazer algum comentário sobre a sua experiência nessa pesquisa?

Após as sessões e entrevistas, as gravações foram escutadas e transcritas, e o caderno de campo com anotações foi analisado. Essa etapa foi importante para lapidar os dados brutos da gravação. Em seguida, as transcrições foram inseridas no programa MAXQDA 
(VERBI, 2019). Nesta etapa, os textos das transcrições foram analisados para que fossem colocados os códigos. Através dos códigos foi possível destacar trechos considerados importantes e relacioná-los com alguma questão do estudo, por vezes usando a mesma etiqueta em momentos que correspondem a pontos semelhantes.

Foram utilizados diferentes códigos para as entrevistas e as sessões de jogo, justamente pelo fato das questões apresentadas nas entrevistas serem diretamente, e abertamente, levantadas pela mediadora, principalmente a partir das perguntas do roteiro. Já nas sessões de jogo, os conceitos, as opiniões e as demais falas dos participantes foram elaboradas de forma natural, a partir do jogo e de suas ações, sem intervenção da mediadora.

A análise qualitativa do material foi feita a partir de Minayo (2017). Segundo a autora:

$\mathrm{O}$ investigador qualitativo deve estar atento à construção de instrumentos e "dicas" que considerem a abrangência da situação que vai estudar. No entanto, muito mais do que a

uma mera aplicação desses instrumentos, tenha certeza de que sua presença, sua interlocução, seus estranhamentos e suas indagações passam a ser vivências em intersubjetividade quando estão no campo, gerando um conhecimento (MINAYO, 2017).

Em seu trabalho, Minayo (2017) defende que a pesquisa qualitativa trabalha atenta a dimensões socioculturais que se expressam por meio de crenças, valores, opiniões, representações, formas de relação, simbologias, usos, costumes, comportamentos e práticas.

Além disso, a autora fala que, de acordo com sua experiência em pesquisas qualitativas, as questões que aparecem durante o trabalho de campo ajudam a entender, corroborar e confrontar o referencial teórico, e vice-versa.

\section{Resultados e Discussão}

\section{Sessão de jogo}


$\mathrm{Na}$ análise de conteúdo, feita a partir das transcrições das sessões de jogos, foram identificados os seguintes códigos: familiaridade com bioma ( 8 marcações), interesse por conteúdo científico (31 marcações) e contextualização (32 marcações). Alguns momentos foram destacados e serão relatados a seguir:

\section{Contextualização}

Foram consideradas falas de "contextualização", aquelas que envolviam um assunto ou experiência relacionados a um fato ou situação do cotidiano, da História, do mundo e atualidades, em geral. Isso pôde ser observado em momentos, como:

Mestre do jogo (Curupira): Beleza... ele falou o nome da empresa. Irrelevante.

Jogador (Iara): Sem merchan.

Mestre do jogo (Curupira): Concreforte, pronto... não, como é que é? Odebrecht.

Jogador (Caipora): Faz sentido.

Nesse momento do jogo, os participantes estavam no bioma Mata Atlântica, querendo saber a empresa responsável pelos prédios ilegais que estavam sendo construídos na área em questão. $\mathrm{O}$ mestre do jogo utilizou uma empresa brasileira mundialmente conhecida para nomear a empresa do jogo. É relevante destacar a fala do participante Caipora, que também foi destacado no caderno de campo. Enquanto fazia seu sutil comentário em relação à empresa, fez uma cara interpretada como de desagrado.

Jogador (Caipora): Eu peço para que as harpias fiquem comigo, porque vai ter uma entrada triunfal, tem que ser épico. Tocando Barracuda e tudo. Eu aponto lá e falo que a galera tá destruindo, e que preciso da ajuda delas para resolver.

Esse foi outro momento em que um tópico do cotidiano do jogador foi trazido para o jogo. Ele relacionou a música Barracuda, da banda norte-americana Heart, do álbum Little Queen (1977), como fundo sonoro do ato de seu personagem Caipora chegar com um exército de animais, sendo carregado por duas harpias em voo, que o jogariam em cima de um dos vilões, no bioma da Amazônia.

\section{Familiaridade com Bioma}


Foi destacado como familiaridade com bioma, os momentos do jogo em que os jogadores demonstravam de pouco a muito conhecimento do bioma em que estavam jogando, e dos outros que eram apresentados no mapa.

Mestre do jogo (Curupira): Vocês estão na Floresta da Tijuca. Conhecem a Floresta da Tijuca?

Jogador (Iara): Não.

Jogador (Caipora): Não.

Jogador (Saci): Eu já fui uma vez.

Mestre do jogo (Curupira): Já foi no Parque Nacional da Tijuca?

Jogador (Caipora): Cara, eu não lembro! Se eu fui, foi muito pequeno.

Jogador (Boitatá): Eu fui uma vez só.

Jogador (Iara): É aquele que tem o zoológico?

Jogador (Curupira): Não, o zoológico é na Quinta da Boa Vista.

Jogador (Boitatá): O outro só em Niterói.

Jogador (Iara): Tô mal...

Risadas
Mestre do jogo (Curupira): Mas vocês já foram no Jardim Botânico? Parque Lage? Então, é referência de Mata Atlântica que vocês podem ter.

Esse trecho do jogo é referente ao início do desafio da Mata Atlântica. É interessante observar que, apesar dos jogadores viverem no estado do Rio de Janeiro, que pertence ao bioma Mata Atlântica, eles têm poucas referências das características, e dos locais que melhor representam essas características.

Jogador (Caipora): Você sempre morou aqui, borboleta?

\section{Mestre do jogo (Curupira): Eu? Não!}

Jogador (Caipora): Não?

Mestre do jogo (Curupira): Eu vim de outro lugar! Vim de um lugar que tinha muitas árvores grandes e muitas flores. Não era tão frio quanto aqui.

Jogadora Iara e Jogador Saci batem com as canetas diversas vezes na parte do mapa escrito Amazônia

Embasando ainda melhor o que foi dito anteriormente, o trecho acima foi retirado do desafio do bioma Pampa, e as características que o mestre do jogo dá para o local de origem da borboleta podem ser relacionados com mais de 
um bioma, inclusive Mata Atlântica. Mas, rapidamente, o bioma que foi imaginado por dois dos jogadores foi Amazônia. Apesar da Amazônia ser uma realidade mais distante da Mata Atlântica para os jogadores, é notada uma maior familiaridade dos participantes em relação a ela. Isso, provavelmente, se deve ao fato de ser o bioma mais popular do Brasil, sempre evidente nos jornais, filmes, até mesmo representando o país no exterior, devido sua enorme importância.

\section{Interesse por conteúdo científico}

Durante as sessões de jogos muitas informações foram trocadas, sobre diversos conteúdos, inclusive e principalmente, científicos. Esses momentos foram retratados como "interesse por conteúdo científico".

Jogador (Caipora): Tem cobra coral falsa?

Mestre do jogo (Curupira): Tem! A falsa e a verdadeira, a diferença é nas listras!

O jogador apresentado no trecho anterior manteve o celular ao lado, durante as sessões, para fazer pesquisas tanto relacionadas ao seu personagem Caipora, quanto às curiosidades científicas que apareciam ao decorrer das histórias. Frequentemente, ele compartilhava com o grupo as imagens e outras informações que poderiam ser úteis.

Jogador (Saci): Eu pego umas ervas do chão, boto no meu cachimbo e acendo.

\section{Risadas}

Mestre do jogo (Curupira): Qual erva você pegou? Você é um especialista em ervas. Vou te dar uma lista de ervas da Amazônia para não passar batido e você aprender alguma coisa nesse turno. Afinal, é um jogo instrutivo. Plantas medicinais da Amazônia, a farmácia do índio: açoita-cavalo ajuda na circulação, colesterol e pressão alta, alcaçuz que é anti-inflamatório, alecrim contra febre, histerismo e nervosismo, boldo caso esteja ruim da barriga, cáscara sagrada para prisão de ventre, confrei que estimula os glóbulos vermelhos e é ótimo cicatrizante. Você tá vendo tudo aí perto de você.

Jogador (Saci): Vou fumar alecrim, ficar relaxadão.

Esse momento também foi destacado no caderno de campo, o qual o jogador mencionado parecia um pouco perdido no desafio, sem saber exatamente como agir, e decidiu não fazer nada muito relevante em seu turno, para que fosse passado para o participante seguinte. O mestre do 
jogo, percebendo que esse jogador não tinha feito ações muito relevantes há, pelo menos, duas rodadas, instigou o participante a ter uma atitude mais completa, explicando que ele aprenderia, pelo menos, alguma coisa a partir de sua ação. Essa atitude pode terminar servindo como estímulo aos jogadores menos entrosados com o desafio.

\section{Jogador (Boitatá): Como a borboleta come?}

Mestre do jogo (Curupira): Ela tem língua..

Jogador (Caipora): Ela tem língua, ela só lambe?

Mestre do jogo: É, uma espirotromba.

Jogador (Caipora): Espirotromba?

Jogadora (Iara): Tipo um sapo?

Mestre do jogo: (Curupira) Ela lambe o pólen, e dentro da espirotromba ela tem um canal que suga as coisas.

Jogador (Caipora): Espirotromba... vivi 26 anos da minha vida sem saber que existia isso.

Esse momento do jogo foi interessante devido ao compartilhamento de um conteúdo científico bastante especializado da Entomologia. Ainda assim, o mestre do jogo explicou tudo de uma forma bastante facilitada e visual, o que pode ser comparado a uma das formas de se passar conteúdo científico ao público não especializado, da Divulgação Científica.

Jogadora (Caipora): Posso invocar animais selvagens tipo tigres?

Jogadora (Boitatá): Tigres?

Mestre do jogo (Curupira): Só pode animais do bioma, tigre é da Ásia. Você pode invocar uma onça.

No começo do jogo, quando o personagem Caipora é apresentado aos jogadores, e é dito que ele pode tanto se comunicar como invocar animais, é explicitado que essa última habilidade só inclui animais do bioma em questão. É comum que animais de outros continentes como tigre, elefante e leão sejam mais conhecidos pelos brasileiros, pois frequentemente são apresentados às crianças antes de animais da fauna brasileira (Scalfi, 2013). Sendo assim, é comum as pessoas terminarem incluindo esses animais à realidade brasileira, quando se pensa na fauna local.

\section{Grupo focal}

Durante as entrevistas em grupo focal, diversos assuntos foram levantados a partir das perguntas do roteiro apresentado anteriormente. Serão destacados aqui, alguns momentos em que 
os jogadores falaram abertamente sobre

Contextualização (29 marcações), Divulgação

Científica (10 marcações), relato da experiência (53 marcações), primeiro contato com informação de teor científico (14 marcações), Conhecimento prévio e interdisciplinaridade (20).

\section{Contextualização}

$\mathrm{Na}$ análise das entrevistas em grupo focal, este termo se diferencia da "Contextualização" codificada na sessão de jogo, justamente por não ser feita a partir de interpretações das ações do jogo, e sim através de elementos que terminam contextualizando a fala dos participantes.

Jogadora (Iara): Você tentar conscientizar alguém que escolheu fazer o errado ou escolhe ter essa postura por ganância, orgulho, dinheiro...é muito complicado, é você bater numa porta e a pessoa não estar aberta a esse diálogo. Eu acho que é muito mais fácil você chegar e convencer pessoas em microescala, tipo a não usarem mais copo descartável e não comprarem de produtores que tem mão de obra escrava. É muito mais tangível do que eu chegar e fazer a Greta Thunberg, ir numa fazenda e mandar o dono parar e pensar no futuro do filho dele. Ele não vai ficar nem aí, e aí o que você vai fazer?

Mediadora do grupo focal: Como vocês lidam com esses problemas ambientais que a gente viu aqui hoje na vida real?

Jogador (Iara): Sei lá, reciclando...

Jogador (Boitatá): Você não recicla nada, cara.

Jogador (Iara): Não tem muita coisa que a gente possa fazer, eu reciclo pilha. Levo para a faculdade que tem um lugar que recicla pilha.

Jogador (Saci): Não jogo lixo na rua.

Mediadora do grupo focal: A gente viu aqui hoje desmatamento, construções inapropriadas, biopirataria, queimada...

Jogador (Caipora): Assim, eu detesto pássaro em gaiola, detesto. Nunca compraria, mas é o máximo.

Mediadora do grupo focal: Vocês chegam a interferir nas ações das outras pessoas? Chamando atenção e tal...

Jogador (Boitatá): É, eu não me amarro numa árvore para ela não ser cortada.

Jogador (Caipora): As pessoas mais velhas...pô, como tu vai mudar a cabeça do teu avô? Tu só não passa pra próxima geração. Teus primos, teus filhos, você não vai ensinar coisa errada.

Jogador (Boitatá): Igual o que aconteceu agora na Austrália, que queimou tudo. Isso foi horrível os animais queimaram vivos. 
Mediadora do grupo focal: Como vocês lidam com esses problemas ambientais na vida real?

Jogadora (Iara): Fico revoltada.

Jogadora (Saci): Eu vejo com tristeza, muita tristeza quando vejo queimando aqui, em outros países...fico triste.

Jogadora (Caipora): Eu compartilho essas coisas, mas não muito.

Jogadora (Iara): Eu uso o Twitter pra compartilhar as denúncias.

Jogadora (Caipora): Cheguei num momento que acho que compartilhar é meio inútil, só fico com raiva. Acompanho páginas que me deixam a par dos problemas e só.

$\mathrm{Na}$ época das sessões, as mídias e redes sociais estavam informando bastante sobre as queimadas que ocorreram aqui no Brasil, na Amazônia, e as que aconteceram na Austrália. Ambas tiveram repercussão mundial. Apesar dos participantes demonstrarem empatia com os problemas que foram apresentados no jogo e que aconteciam na vida real, achavam que não poderiam fazer muita coisa para mudar em grande escala. Interessante observar, junto a isso, que quando questionado, durante o grupo focal, o que eles fariam se tivessem os poderes dos seus personagens, a maior parte não comentou que utilizaria para resolver os problemas ambientais.

Jogador (Caipora): Pô, eu ia querer falar com meu cachorro, cara. Falar com os animais, invocar os animais... eu ia me sentir uma princesa da Disney.

Jogadora (Iara): Eu acho que seria legal usar a persuasão, mas acho que no direito eu já uso.

Minha voz só não é mágica.

Jogadora (Boitatá): Eu ia adorar manipular as pessoas e de ter visão noturna.

Jogador (Saci): Eu iria pregar várias peças. Agora aqui pensando eu vejo que poderia pregar mais peças durante o jogo

Mediadora do grupo focal: Se vocês tivessem essas habilidades dos seus personagens na vida real, o que vocês fariam?

Jogadores: Pô!!!

Jogador (Boitatá): Defender a natureza não seria tão relevante.

Mediadora do grupo focal: Você iria usar para fazer outras coisas?

Jogador (Boitatá): Provavelmente.

Jogador (Saci): Eu sairia matando os bandidos. Jogador (Iara): Eu seria um deus, controlo a água e o corpo é $70 \%$ água... 
Mediadora do grupo focal: Se vocês tivessem a habilidade dos personagens de vocês, o que vocês fariam?

Jogadora (Boitatá): Ui!

Risadas

Jogadora (Caipora): Eu ia gostar de falar com os animais.

Jogadora (Saci): Eu não faria o que eu fiz não, com certeza. Matei muito.

Jogadora (Iara): Eu ia adorar as características, seria muito útil.

\section{Divulgação Científica}

Um tema diretamente abordado durante os grupos focais foi a Divulgação Científica, assunto central para este trabalho. Divulgação Científica é um assunto que tem se popularizando entre os meios de informação, principalmente redes sociais, no Youtube, Instagram, Twitter, Facebook, entre outros. Mas o fato de as pessoas ficarem mais familiarizadas com o epíteto não significa necessariamente que realmente saibam o que significa e abrange. Por isso, foi importante perguntar aos jogadores o que eles entendiam por Divulgação Científica.
Jogadora (Iara): Eu acho que é você levar a Ciência às pessoas de forma que ela vá compreender. Porque se você me mostrar um artigo científico, eu vou olhar e não vou entender nada. Se você vier e mostrar alguma coisa que seja na minha linguagem, eu vou estar muito mais aberta e vou conseguir entender e aplicar muito mais. É você divulgar o conhecimento que foi feito, mas de uma forma compreensível para todos.

Jogador (Saci): Uma forma mais lúdica, né? Porque, sei lá, têm várias formas de passar a informação. Por exemplo, o que eu vejo nesse jogo aqui é que tem uma mensagem principal clara a ser passada, mas é uma mensagem que não é passada de uma maneira formal, é passada de uma forma muito informal. Eu acho que é até mais eficaz do que daquela maneira muito quadrada, porque quando é quadrada, você pensa... Ah, esse papo de novo, não, ou, ah, não aguento mais isso, não. É, de uma maneira mais atraente.

Jogadora (Boitatá): Mais divertida.

Jogador (Caipora): Eu acho que é tipo aqueles vídeos que tem no Youtube, explicando x coisa para pessoas de diferentes idades e níveis escolares. Explicando computação quântica para uma criança, um senhor, um historiador e um cara que é formado em computação. Maneiras diferentes de explicar para pessoas diferentes. 
Mediadora do grupo focal: o que é Divulgação

Científica para vocês? Não tem certo e nem errado.

Jogador (Saci): Pesquisa.

Jogador (Caipora): Não, pra mim é mais que pesquisa. É você, a partir de uma base, tentar levar uma coisa que se aproxime mais da verdade, sem dizer que aquilo é $100 \%$ de verdade. Porque, pra mim, Ciência não é aquilo que é A verdade em si, mas o quão menos errado aquilo tá. Por exemplo, a gente não tem noção sobre o que é a gravidade engloba daqui até o fim do universo, a gente sabe o que não acontece, já que ela existe. Você nunca vai jogar uma maçã e ela vai subir. Mas, talvez, a gravidade tenha efeito que a gente ainda não mediu. Então, a Ciência nunca vai dizer que tem $100 \%$ da compreensão da gravidade, mas o que ela sabe até agora. É constatar algo e com esse algo usar, saber os fenômenos e entender melhor a Terra. E a Divulgação Científica leva as informações pro público. Infelizmente tá difícil, porque tem muitas pseudociências, o pessoal que é coach, a galera da terra plana, porque parte do pressuposto de querer comprovar aquilo que acham que tá certo e não dão chances para descobrir que está errado. A Ciência não é assim. Ela parte da hipótese e a pseudociência da conclusão.

Mediadora do grupo focal: O que é Divulgação Científica para vocês?
Jogadora (Boitatá): É para dizer o que eu penso ou o que as pessoas acham que é?

Mediadora do grupo focal: $100 \%$ o que você pensa.

Jogadora (Boitatá): Bom, pra mim deveria ser... divulgação da Ciência que é feita de resultados científicos que são obtidos dentro da academia. Se a gente for parar e pensar em palavras.

Mediadora do grupo focal: Mas divulgação para quem, quando você falou isso?

Jogadora (Boitatá): Aí tanto faz, pode ser pros pares. Então, vamos supor, estou lá eu dizendo os resultados que eu obtive na minha pesquisa... estou dizendo para você, e eu posso pegar isso e mostrar pra o seu Zé da bomba, se ele vai entender ou não, não interessa, eu divulguei. Isso eu acho que é Divulgação Científica ao pé da letra. E é o que eu acho que é feito por aí, com palavras impossíveis do povo traduzir, textos, em sua maioria, em línguas que o povo não vai entender. Então, acho resultados numéricos, gráficos, teóricos, absurdamente inatingíveis pela população, em geral, é isso que eu vejo sendo Divulgação Científica, termina sendo para os pares. Pode ser feita pro público, mas não atinge, não supre as necessidades do momento. $\mathrm{O}$ que é diferente, para mim, do que seria uma popularização. Que, aí sim, você dá pro povo o que ele precisa saber, do jeito que ele pode entender, dentro das habilidades dele, não dentro da do cientista, tem que descer os degraus da sua escada e 
passar sua informação dentro das habilidades do povo.

Jogadora (Iara): Eu concordo com o que ela falou. Eu não saberia falar melhor, não é nem para copiar a resposta de ninguém, é porque é uma realidade.

Jogadora (Caipora): Eu nunca tinha ouvido falar, mas tentando dar um significado a isso seria divulgar o conteúdo científico mesmo.

Jogadora (Saci): Eu acho que é um setor muito importante. Levar as mensagens e falar para as pessoas como funciona...Ah, pesquisador descobriu essa vacina assim, trabalha assim. Só que, na minha opinião, não tem valor para as autoridades, acho que deveria ser mais valorizado. Vocês trabalham com amor, cientista trabalha com amor, mas o governo, as autoridades não valorizam. Isso me magoa. Devia ter financiamento, porque se gasta dinheiro fazendo isso.

As diferentes perspectivas foram muito interessantes de serem observadas. Enquanto algumas respostas se aproximaram bastante do que se conceitua Divulgação Científica, na literatura (apresentada na introdução deste artigo), outras se mostram coerentes com o que ocorre com a Divulgação Científica na prática.
Alguns profissionais se intitulam divulgadores científicos, ou se propõem a divulgar a Ciência, mas terminam apresentando à sociedade uma versão de seu trabalho com poucas mudanças na linguagem e poucos instrumentos facilitadores nessa tradução. De acordo com Brockington e Mesquita (2016), mesmo a Divulgação Científica contribuindo para a aproximação entre Ciência e Sociedade, quando feita de forma descuidada pode resultar em consequências indesejadas.

\section{Relato da Experiência}

Quando perguntado aos jogadores o que eles achavam da experiência de jogos como "O Chamado do Curupira", as respostas se mostraram positivas e, segundo eles, o grande interesse em RPG relacionados à Ciência pode ser visto devido à grande liberdade que o jogo oferece aos participantes em relação a escolhas e ações.

Jogador (Caipora): Essa experiência de RPG foi diferente, porque você se envolve mais com a história, tem todo um contexto por trás.

Jogador (Iara): Tem a imersão, você tá mais envolvido, e não tem um caminho definido. 
Jogador (Boitatá): É cativante. Qualquer coisa pode virar RPG, e dentro do universo que você quer trabalhar você dimensiona. Por exemplo, um que envolva Física, você tenta abordar os fenômenos que ocorrem no mundo, e explorar isso para pessoas de diferentes idades e fases escolares. Pra galera que joga RPG, uma coisa que a gente passa um tempo discutindo é a Física da situação, 8 metros ou não, norte vai atingir a floresta ou não, quanto o macaco consegue carregar quanto de peso.

Jogadora (Caipora): É muito diferente de tudo que eu já joguei, a história é meio aberta.

Jogadora (Iara): Acho que fixa mais a história, não sei se vocês assistiram a novela das 7 que já tá terminando, eles liam uns trechos do livro e representavam e eu entendia melhor o que eles queriam dizer. E essas coisas fixam mais para nós que estamos participando ou assistindo.

Apesar de um estranhamento inicial, da parte dos que não tinham experiência no estilo de jogo, os participantes falaram de forma bastante positiva da liberdade de ser, estar e fazer que o jogador tem, durante uma sessão de RPG. Segundo eles, há uma maior absorção de conceitos e conteúdo quando você vive, experimenta na prática.

\section{Primeiro contato com informação de teor científico}

Esse código estava relacionado à percepção dos jogadores em relação a primeiro contato com assunto de teor científico durante as sessões. Algumas das respostas serão apresentadas a seguir:

Jogador (Caipora): O Pampa eu não conhecia, também não sabia que boitatá era uma cobra. E teve a espirotromba, que eu também achei fantástico.

Jogador (Boitatá): Eu não sabia sobre os biomas, o que os bichos comem, o peso, tamanho, bastante coisa de animais.

Jogador (Saci): As espécies de cada bioma são novidades pra mim.

Jogador (Iara): Olha, eu vejo muito Discovery Channel, mas essas espécies eu não sabia, não. Nem sabia que o bugio era daqui.

Jogadora (Boitatá): Sou bióloga, mas quando fala Pampa não me vem nada.

\section{Conhecimento prévio e interdisciplinaridade}

A partir da pergunta "quais desafios vocês resolveram baseados em conhecimentos prévios?", os participantes demonstraram uma 
utilização de conteúdos aprendidos ao decorrer de suas vidas tanto na escola, quanto de experiências vividas, de filmes, jogos, entre outras formas de entretenimento assistidos. Um fator que foi adicionado ao código de conhecimentos prévios, e que sempre o acompanhou, foi a interdisciplinaridade. Apesar de, nas escolas, as disciplinas serem ensinadas separadamente (geografia, biologia, química, física, história, entre outros) na vida real, é comum observar todo esse conteúdo misturado, às vezes sendo difícil saber onde um termina e outro começa

Jogadora (Iara): Acho que eu tentei, desde o começo, usar isso. Não só no folclore, mas também resgatar o que eu sabia de geografia, ciências, do lugar que a gente tava...

Jogador (Caipora): Eu lembrei de experiência de vida, de um modo geral, mesmo. Sei lá, filmes, jogos, situações que eu passei e é interessante aplicar. Cada um quer aplicar de uma forma diferente.

Jogador (Boitatá): Quase tudo. Usei geografia, física, biologia. É vida paralela.

Jogador (Caipora): Eu sabia que, se você tirar bactéria da água, os peixes morrem. Por causa do equilíbrio.
Jogadora (Saci): Eu sabia muito do folclore, porque trabalhei muito com criança, fui alfabetizadora. Para mim foi bom, porque eu recordei.

\section{CONCLUSÃO}

Estas primeiras experiências sugerem que a utilização de um Jogo Sério, especificamente na forma de um RPG, na apresentação e na popularização de assuntos relacionados à Ciência pode ser muito produtiva e permitir que os jogadores se sintam engajados com a história e a resolução desses problemas. Especialmente, tendo-se em vista que o meio ambiente é um tema importante na atualidade e fator que é essencial para o equilíbrio e as condições que regem a vida no planeta.

De acordo com as opiniões dos participantes, é muito importante que o jogo que tenha a preocupação de passar um conteúdo científico se importe em entreter, em ser divertido, exatamente como os jogos sérios se propõem. Para eles, a experiência com o RPG foi bastante agradável justamente por não ser um jogo no formato e estilo de jogo educativos, que remetam à sala de aula. 
Seria utópico imaginar que a partir de uma experiência como essa, as pessoas possam mudar radicalmente seus hábitos ou se tornarem ativistas de causas ambientais. Mas, o fato dos jogadores serem apresentados a problemas ambientais que ocorrem no país, e de animais e plantas serem mostrados como seres que correm perigo por ações que os próprios seres humanos fazem já pode gerar uma reflexão que, juntamente a outros fatores, pode se concretizar na mudança de atitudes.

Independente de experiências anteriores ou não com RPGs, o conteúdo conseguiu ser exposto em todas as sessões, e os próprios jogadores admitiram ter aprendido, se entretido e gostado da experiência. O que nos leva a acreditar que a mecânica dos Role Playing Games pode ser apresentada de forma facilitada e adaptada para incluir pessoas independente do seu nível de experiência, com a finalidade de comunicar um conteúdo relevante.

\section{Relacionado à Divulgação Científica,} também se percebe uma boa conceituação dos participantes, de uma forma geral. E no momento em que é questionado se o jogos, como o que foi vivenciado por eles, poderiam ser uma forma efetiva de DC, as respostas foram positivas, o que nos leva a creditar que RPGs e Divulgação Científica podem ser uma dupla efetiva na apresentação de conteúdos científicos, de maneira ativa e contextualizada.

A partir do caso aqui relatado, acreditamos que o Role Playing Game se mostrou efetivo instrumento no incentivo à popularização e contextualização da Ciência. Outros recortes dos dados levantados serão abordados futuramente, os quais possivelmente revelarão novas possibilidades para o uso dos RPGs relacionados à popularização conteúdo científico.

\section{Apoio}

Coordenação de Aperfeiçoamento de Pessoal de Nível Superior - Brasil (CAPES)

Mestrado Acadêmico em Divulgação da Ciência, Tecnologia e Saúde - FIOCRUZ

Programa Pesquisa Produtividade da Universidade Estácio de Sá — UNESA 


\section{Referênclas}

ALBAGLI, S. Divulgação científica: informação científica para cidadania. Ciência da Informação, v. 25, n. 3, p. 396-404, 1996.

BECKER, K. What's the difference between Serious Games, educational games, and gamebased learning?. The Becker Blog. 2018. Disponível em

http://minkhollow.ca/beckerblog/wp$\underline{\text { content/uploads/ }}$ 2018/02/game-gblgamification-2.png. Acesso em 15 de outubro de 2020.

BROCKINGTON, G.; MESQUITA, L. As consequências da má divulgação científica. Revista da Biologia, v. 15, n. 1, p. 29-34, 2016.

BUENO, W. C. Comunicação cientifica e divulgação científica: aproximações e rupturas conceituaiss. Informação \& Informação, v. 15, n.1, p. 1-12, 2010.

BURNS, T. W.; O'CONNOR, D. J.; STOCKLMAYER, S. M. Science communication: a contemporary definition.
Public Understanding of Science, v. 12, n. 2, p. 183-202, 2003.

DA-SILVA, E. R.; COELHO, L. B. N. Os personagens de HQs como estratégia para popularizar a Entomologia aquática. Revista Científica Semana Acadêmica, v. 1, n. 73, p.1-14, 2015.

GODOY, A. S. Introdução a pesquisa qualitativa e suas possibilidades. Revista de Administração de Empresas. São Paulo, v. 35, n. 2, p. 57-63, 1995.

HSIAO, H. A Brief Review of Digital Games and Learning. DIGITEL 2007, Los Alamitos, CA, USA: IEEE Computer Society. 2007.

HUIZINGA, J. Homo ludens. Edição 6, trad. João Paulo Monteiro. Perspectiva, São Paulo, 2020.

IERVOLINO, S. A.; PELICIONI, M. C. F. A utilização do grupo focal como metodologia qualitativa na promoção da saúde. Revista USP, v. 35, n. 2 , p. 115-121, 2001.

KISHIMOTO, T. M. Jogo, brinquedo, brincadeira e a educação. Cortez editora, 2017. 
MCFEETORS, P. J.; PALFY, K. Educative experiences in a games context: Supporting emerging reasoning in elementary school mathematics. The Journal of Mathematical Behavior, v. 50, p. 103-125, 2018.

MINAYO, M. C. amostragem e saturação em pesquisa qualitativa: consensos e controvérsias. Revista Pesquisa Qualitativa, v. 5, n. 7, p. 1-12, 2017.

NEVES, R.; MASSARANI, L. O olhar das crianças sobre uma exposição interativa. Divulgação científica e museus de ciências: O olhar do visitante-Memórias do evento, v. 1, n.1, p. $65-72,2016$.

SANDIFORD, P. Participant observation as ethnography or ethnography as participant observation in organizational research. In STRANG, K. The palgrave handbook of research design in business and management. New York: Palgrave Macmillan, 2015, p. 411-446.

SOUZA, E. S. Uso de jogos de Role Playing Game (RPG) como uma estratégia possível de aprendizagem de conteúdos de biologia na educação de jovens e adultos. Interdisciplinary Scientific Journal, v.2, n.3, p. 384-396, 2015.

VASCONCELLOS, M. S. Comunicação e Saúde em Jogo: Os videogames como estratégia de promoção da saúde. Tese (Doutorado em Informação e Comunicação em Saúde) - Instituto Oswaldo Cruz, Rio de Janeiro, p. 119. 2013.

VERBI, S. MAXQDA 2020 Online Manual. Novembro, 2019. Disponível em: maxqda.com/help-max20/welcome. Acesso em: 12/05/2020.

YIN, R. K. Case study research: Design and methods. $5^{\circ}$ edição. Califórnia: Sage, 2014 